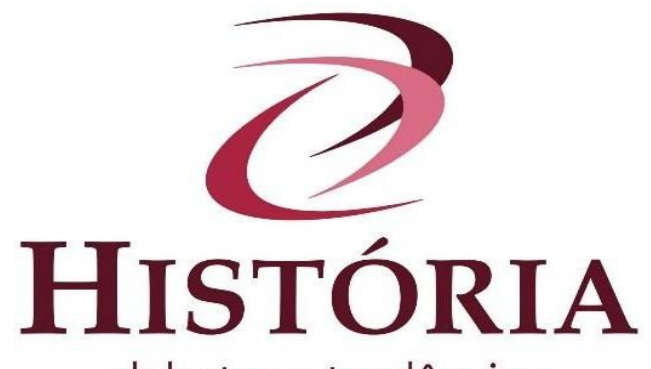

\title{
O conceito de etnogênese: o dinamismo histórico das identidades coletivas
}

\section{The concept of ethnogenesis: the historical dynamism of collective identities}

\section{El concepto etnogénesis: el dinamismo histórico de las identidades colectivas}

Leandro Goya Fontella ${ }^{\mathrm{i}}$

Resumo: $\mathrm{O}$ arcabouço analítico da etnogênese surgiu e se consolidou nas últimas cinco décadas por meio de um profícuo diálogo entre antropologia e história. As investigações oriundas dessa abordagem questionaram as interpretações que percebiam povos indígenas como portadores de uma essência de indianidade que acabavam perdendo em processos de aculturação em virtude do avanço colonial europeu. De modo geral, a perspectiva conceitual da etnogênese procura conciliar a relatividade das categorias analíticas, o caráter processual de formação e desaparecimento das identidades sociais, a historicidade das sociedades investigadas e identificar as tensões explícitas e implícitas na esfera das relações de dominação.

Palavras-chave: Etnificação. Etnogênese. História intelectual.

\begin{abstract}
The analytical framework of ethnogenesis has emerged and consolidated over the past five decades through a fruitful dialogue between Anthropology and History. Investigations stemming from this approach questioned the interpretations that perceived indigenous peoples as carrying an essence of indianness that ended up losing in acculturation processes due to the European colonial advance. In general, the conceptual perspective of ethnogenesis seeks to reconcile: the relativity of analytical categories, the procedural character of the formation and disappearance of social identities, the historicity of the investigated societies and the identification of explicit and implicit tensions in the sphere of relations of domination.
\end{abstract}

Keywords: Ethnification. Ethnogenesis. Intellectual history.

Resumen: El marco analítico de la etnogénesis ha surgido y consolidado en las últimas cinco décadas a través de un fructífero diálogo entre antropología e historia. Las investigaciones derivadas de este enfoque cuestionaron las interpretaciones que percibían a los pueblos indígenas como portadores de una esencia de indigenidad que terminó perdiendo en los procesos de aculturación debido al avance colonial europeo. En general, la perspectiva conceptual de la etnogénesis busca conciliar: la relatividad de las categorías analíticas, el carácter procesal de la formación y desaparición de las identidades sociales, la historicidad de las sociedades investigadas y la identificación de tensiones explícitas e implícitas en la esfera de las relaciones de dominación.

Palabras clave: Etnificación. Etnogénesis. Historia intelectual. 


\section{Introdução}

Neste texto busco discorrer acerca das premissas conceituais que sustentam os estudos de etnogênese. Nas últimas décadas, os estudos sobre etnogênese vêm contribuindo para reconfigurar as análises antropológicas e históricas sobre as experiências das populações indígenas. O diálogo e o intercâmbio teórico-metodológico entre história e antropologia têm ensejado novos objetos e enfoques de pesquisas. Preceitos capitais a cada uma das disciplinas refinaram as investigações destes dois campos de estudo. Por exemplo, enquanto os historiadores aprenderam a considerar com mais afinco o caráter relativo das categorias e a construção das identidades coletivas, os antropólogos passaram a prestar atenção na historicidade das configurações sociais (REVEL, 1996 apud BOCCARA, 2005a).

As interpretações que emergem dos exames que se pautam por estas novas abordagens demonstram que, mesmo antes do contato colonial, as populações indígenas configuravam-se como sociedades historicamente dinâmicas, isto é, viviam em constante processo de transformações sociais, políticas, econômicas, culturais, espaciais, etc. Além disso, apesar dos profundos e mesmo devastadores impactos provocados pelo processo de conquista europeia em solo americano, tais sociedades possuíam ferramentas simbólicas e materiais que lhes permitiram elaborar estratégias políticas e econômicas para interagir com os europeus. Assim, diante do tensionado e instável contexto colonial, com base em suas experiências prévias de como agir em momentos de crise e lidar com o imponderável, as populações nativas americanas foram capazes de desenvolver meios para resistir e/ou se adaptar ao ordenamento social emergente, exercendo considerável influência sobre a forma adquirida por este. De acordo com Jonathan Hill, estas análises "se afastaram de noções passadas de povos indígenas americanos como um conglomerado de sociedades estáticas e isoladas que estavam totalmente desprovidas de recursos para lidar com as mudanças maciças postas em movimento durante o período colonial" (1996, p. 7).

Um dos grandes avanços dessa perspectiva etno-histórica se constitui na desconstrução de certos pressupostos conceituais que acabavam por estabelecer dicotomias artificiais sobre as experiências históricas indígenas. Refiro-me especificamente a certa diretriz interpretativa que produziu (mesmo que involuntariamente) um discurso etnohistórico de viés essencialista em que as sociedades indígenas são apresentadas como se contassem com uma essência cultural. Tal postura gera uma consequência explicativa que vigorou por considerável tempo, estabelecendo uma trajetória linear entre dois polos 
antagônicos: de um lado, situava-se a pureza cultural original e, de outro, a cultura contaminada. ${ }^{\text {ii }}$

Assim, as culturas indígenas foram idealizadas como resíduos de um estágio histórico primitivo do qual não se desprendiam devido ao apego à essência cultural. Nesse sentido, as transformações provocadas pelo contato colonial são compreendidas como um processo anômalo imposto sobre populações que se caracterizavam pelo imobilismo histórico e que acabaram por corromper a pureza das culturas originárias. Ademais, as relações dos povos nativos com os euro-americanos são avaliadas de forma estanque em termos de resistência ou aculturação. ${ }^{\text {iii }}$ A assimilação é tida como o horizonte da aculturação, e a preservação de uma tradição imemorial como perspectiva de resistência aos estrangeiros. Logo, a sociedades nativas estariam em frente a um inexorável dilema: condenadas ao desaparecimento ou, então, presas em um arcaísmo eterno (BOCCARA, 2005a).

Em última análise, reificadas como povos sem história, restaria um campo de alternativas bastante restrito para as sociedades indígenas, partindo da resistência com a consequente extinção biológica, passando pela aculturação traumática dos indivíduos remanescentes já exauridos pelo esforço de resistência, até chegar aos processos de aculturação consensual com a paulatina perda da essência e da identidade cultural. Em contraposição a este quadro interpretativo, os novos aportes conceituais etno-históricos como, por exemplo, etnogênese, etnificação e etnocídio, têm ensejado sofisticadas análises que, por sua vez, apontam que "os processos etnogênicos perpassam toda a história das sociedades coloniais e permeiam a adaptação das sociedades indígenas às pressões europeias" (SALOMON; SCHWARTZ, 1999, p. 444). Além disso, atualmente sabe-se que muitas áreas americanas estavam em condição de efervescência etnogênica mesmo antes da chegada dos europeus. Estudos arqueológicos e relatos coevos indicam que migração, fissão, incorporação e aliança estavam ocorrendo entre as sociedades nativas da América na era pré-contato (SALOMON; SCHWARTZ, 1999).

A compreensão de que os povos indígenas eram resultados transitórios de contínuos processos de transformações rompe com o pilar básico dos estudos essencialistas, ou seja, o argumento de que tais populações estavam cristalizadas no decorrer do tempo em função de conterem uma essência cultural ancestral. Por este ângulo, grupos sociais que, pela concepção essencialista, eram considerados entidades milenares passam a ser percebidos como entidades cambiantes providas de recursos imateriais e materiais para enfrentar contextos diversos, favoráveis ou de adversidades. Estes, por seu turno, podiam ou não acarretar reconfigurações críticas como a fragmentação, a incorporação criativa de 
itens estrangeiros e mesmo a emergência de novas identidades coletivas.

É corrente entre os etno-historiadores que os agrupamentos nativos que emergiram nas primeiras décadas de contato são distintos daqueles que foram inicialmente encontrados, pois são criações coloniais formadas por meio de processos de etnogênese (WHITEHEAD, 1996) e isto é tão ou mais verdadeiro no concernente aos etnônimos, os quais, no mais das vezes, eram atribuídos aos grupos por agentes externos, erigindo uma percepção artificial de que "determinados grupos sempre existiram coerentemente como se fossem 'nações' em territórios delimitados" (CARVALHO, 2006, p. 3).

Nas duas seções que compõem este artigo, discorro sobre os conteúdos conceituais das noções de etnogênese e etnificação, e como eles se converteram em ferramentas importantes para o redimensionamento dos estudos acerca da história das populações nativas americanas e de suas interações com as sociedades colonizadoras.

\section{Dimensões de um mesmo fenômeno: etnogênese e etnificação}

As noções de etnogênese e etnificação são dimensões de um mesmo fenômeno. Enquanto a primeira "remete à capacidade de criação e adaptação das entidades indígenas e à emergência de novas formações sociais", a segunda "serve para caracterizar os dispositivos coloniais (de estado e capitalista) que produzem efeitos de normalização e espacialização e participam da criação do étnico através da reificação das práticas e representações das sociedades indígenas" (BOCCARA, 2005b, p. 45-46).

O primeiro autor a empregar a noção de etnogênese foi William Sturtevant em 1971, quando analisou as origens da etnia seminole do sudeste norte-americano a partir da migração forçada de uma facção creek pressionada pela frente colonial anglo-americana e que acabou mesclando-se com outros grupos indígenas do sul (principalmente o povo conhecido como Red Stick) e com negros escravos fugidos entre os séculos XVII e XVIII. Segundo Sturtevant, a formação dos seminole como um novo grupo indígena, tendo como um dos fatos geradores as tensões coloniais, configura-se como um processo etnogênico. Não obstante, os fenômenos etnogênicos referiam-se exclusivamente à emergência física de novos grupos sociais.

Após este texto original, diversos estudiosos, sobretudo nos EUA, passaram a aplicar o conceito de etnogênese. Na vaga renovadora dessas análises, o próprio conteúdo semântico do termo foi tomando contornos mais amplos e refinados, deixando para trás, por 
exemplo, a acepção puramente biológica na formação de novos arranjos humanos. Assim, a noção de etnogênese constitui-se numa ferramenta conceitual que contribui para caracterizar processos muito diversos de transformações políticas e identitárias de um grupo ao longo do tempo, enfatizando as capacidades de adaptação e criação de povos indígenas, os quais, por sua vez, buscaram estabelecer espaços de autonomia em que pudessem realizar suas próprias avaliações e traçar estratégias para trilhar intrincados processos que produziam novas configurações sociais que não só refletiam as pressões coloniais como também as escolhas dos próprios índios. Nesse sentido, os novos grupos e identidades indígenas não surgiram somente por meio das imposições coloniais, mas das ações indígenas que em muitas ocasiões avaliaram ser mais adequado incorporar elementos materiais e/ou simbólicos exógenos do que negá-los, e das constantes reelaborações de suas próprias identidades (BOCCARA, 2005a).

Em via de regra, o contexto colonial atuou como um catalisador para a emergência de novas identidades e formações sociais indígenas. Isso fez com que num curto espaço de tempo, após o contato inicial com os europeus, as sociedades indígenas se distinguissem significativamente das organizações sociais nativas exististes no período pré-contato. Esta dinâmica de reconfigurações socioidentitárias baseia-se na relação indissociável entre o etnocídio (extinção cultural dos povos) e a etnogênese (surgimento de novas culturas indígenas).

Os dois fenômenos devem ser vistos como aspectos complementares do mesmo processo de transformação sociocultural, o que varia é o predomínio e a intensidade de um ou do outro que estão ligados diretamente ao momento histórico específico de análise. Todavia, como alerta Neil Lancelot Whitehead, quando se está examinando "o destino das formas de organização sociopolítica e suas categorias culturais acompanhantes sob a aparência de identidades étnicas, os processos de etnogênese e etnocídio não são necessariamente indícios da extinção demográfica ou gênese de grupos de pessoas" (1996, p. 34), mas "que novas identidades de grupo foram criadas e as antigas caíram em desuso" (1996, p. 21). Ou seja, etnocídio não é sinônimo puro e simples de genocídio ou extinção biológica de determinadas populações. Trata-se de um termo mais amplo que pode ou não estar associado a este último.

Esta afirmação precisou enfrentar e descontruir um dos axiomas mais estabelecidos nos estudos sobre os povos indígenas coloniais, a saber: o quadro de radical descontinuidade entre as dinâmicas pré e pós-coloniais produzido, sobretudo, pela hecatombe demográfica do século XVI. As análises etno-históricas das últimas décadas, no lugar de se ater 
unicamente à questão do esgotamento das sociedades nativas, problematizaram o surgimento de distintos e divergentes tipos de grupos sociais indígenas no período colonial (MONTEIRO, 2001).

Exemplos disso são as investigações de Whitehead ambientadas no Suriname colonial. Este autor percebeu que alguns refugiados do povo yao se estabeleceram entre o rio Cottica e a foz do Maroni, onde formaram cidades com o Paragoto e Arawak. Porém, mesmo que outras porções de exilados yao tenham sido brevemente dominantes na região de Oyapok, posteriormente desapareceram dos registros históricos. Para o autor, não está claro se o sumiço dos yao dos registros coloniais foi realmente acompanhado por sua extinção demográfica, pois eles podem muito bem ter sido absorvidos como afins por caribes ou arawak, sociedades que se tornaram hegemônicas durante a era colonial (WHITEHEAD, 1996).

Considerável parte das investigações no campo dos processos de etnogênese das sociedades indígenas na era pós-contato debruçou-se sobre um componente fundamental destes: os fenômenos de etnificação. Para a etno-história, tal conceito possibilita acessar as dinâmicas políticas de controle colonial e de estratégias dos povos indígenas. Através dele, se pode problematizar tanto os processos de imposição dos padrões valorativos e de classificação social dos conquistadores, que buscavam estabelecer limites bem definidos para os grupos étnicos, quanto as atitudes tomadas pelos índios para reelaborar suas identidades (muitas vezes assumindo o etnônimo e os espaços impostos pela sociedade colonial) e entabular alianças políticas com os colonizadores para obter acesso a posições e bens almejados (CARVALHO, 2006).

De forma hegemônica, as operações de etnificação obedeceram aos anseios coloniais de classificar as populações nativas em categorias de identificação que, em geral, atendiam a critérios linguísticos, territoriais e do tipo de relação estabelecida com os europeus (amistosas ou hostis). Perante um universo expressivamente complexo de povos aborígenes, os primeiros agentes coloniais buscavam esboçar uma espécie de mapa político da América que lhes fosse inteligível. Para isso, recorriam a categorias de seu próprio universo simbólico como nação. Não tardou para que os procedimentos de classificação das populações nativas produzissem consequências práticas que serviram como balizas para estratégias de controle colonial, pois produziram categorias fictícias naturalizadas e estanques que serviram como referências para, entre outras coisas, estabelecer escalas hierárquicas entre grupos subordinados e não subordinados (e também interna a estes) e impor esquemas arbitrários de territorialização política aos moldes europeus para povos que, 
em boa medida, desfrutavam de razoável mobilidade espacial com base em ciclos naturais e suas sazonalidades.

Em contrapartida, as definições políticas artificiais, inventadas pelos colonizadores, paulatinamente foram sendo absorvidas pelos próprios grupos etnificados em processos de homogeneização cultural. Além disso, como mostra John Monteiro (2001, p. 58), elas se converteram num

aspecto fundamental na formação de alianças e na determinação das políticas coloniais [...] a tendência de definir grupos étnicos em categorias fixas serviu não apenas como instrumento de dominação, como também de parâmetro para a sobrevivência étnica de grupos indígenas, balizando uma variedade de estratégias geralmente enfeixadas num dos polos do inadequado binômio acomodação/resistência.

No norte da América do Sul, os karinya e outros grupos aliados aos holandeses se tornaram conhecidos como caribes, enquanto os lokono, a serviço dos espanhóis, foram rotulados de arawaks. As atribuições foram feitas sem referência ao uso do idioma. A identidade caribe, termo cognato ao canibal e à belicosidade estúpida, foi de fato produzida e reforçada por hostilidades com os espanhóis e não pela distribuição real dos idiomas caribenhos. Os mais destacados caribes na era colonial eram na verdade os kalinago ou caribes ilha, os quais eram povos de fala arawaka, mas que incorporaram elementos culturais caribes por meio das relações mercantis, incluindo até mesmo um dialeto guerreiro com palavras de empréstimo karinya (SALOMON; SCHWARTZ, 1999).

Caribes e arawaks tornaram-se grupos indígenas preponderantes e antagônicos graças às suas bem-sucedidas relações com as sociedades coloniais. Conforme Whitehead, "o resultado geral da interação desses fatores foi que os europeus perderam de vista as mais sutis distinções étnicas entre grupos ameríndios, tendendo a agrupar todos os grupos como aruacas ou caribes" (1996, p. 25-26). Com base nisso, o autor afirma ainda que "tanto a autoafirmação nativa como as definições etnológicas geradas pelo colonialismo europeu trabalharam em conjunto para cimentar as identidades contrastantes de aruaca e caribe nas redes políticas nativas de toda a região norte da América do Sul” (1996, p. 26).

No decorrer do século XVII, na região das grandes planícies meridionais da América do Norte e nas áreas ao leste do Rio Grande, o etnônimo jumano foi relacionado a duas circunstâncias distintas. Num primeiro momento, era um termo genérico que os espanhóis designavam indígenas de determinado caráter cultural e linguístico que se espalhavam por estes vastos territórios. Posteriormente, era uma palavra para se referir a índios desse tipo que atuavam como mercadores (HICKERSON, 1996). 
Com efeito, boa parte dos povos nativos chamava a si mesmos em seus próprios idiomas por expressões como a gente, os homens, o povo. A construção de etnônimos dos grupos araucanos dá um exemplo bastante elucidativo deste processo. Do mesmo modo que muitos outros povos aborígenes, a população conhecida pelos espanhóis como araucanos se chamava a si mesma de che (a gente ou os homens) ou reche (os verdadeiros homens). No geral, esta população utilizava os pontos cardeais para se distinguirem uns dos outros, referiam-se aos povos situados ao norte como picunches e aos grupos sulistas como huilliches. Antes do contato, estas designações não se configuravam em etnônimos fixos; elas referiam-se unicamente à posição relativa de cada agrupamento, pois o norte e o sul eram empregados de acordo com a perspectiva de quem estava utilizando tais termos. Após o contato, os espanhóis passaram a aplicar estes termos nativos de orientação espacial para denominar as populações que ocupavam regiões específicas. Com o passar do tempo, os próprios indígenas adotaram esses etnônimos para se identificar como pertencentes a grupos maiores que suas famílias imediatas ou clãs. Picunches designava os índios de fala araucana que viviam ao norte do rio Biobío, os quais até o século XVIII haviam sido absorvidos pela sociedade colonial e desaparecido como etnia. Huilliches identificavam os nativos que ocupavam o espaço ao sul do rio Tólten, os mais distantes da influência hispânica. E o termo araucano passou a ser empregado somente aos indígenas que ocupavam o território entre os rios Biobío e Tólten. Porém, por volta de meados do século XVIII, os espanhóis começaram a chamar estes pelo etnônimo mapuche, que significa gente da terra. Para além disso, os índios sob esta última designação foram subdivididos em categorias ainda mais tênues de acordo com os locais que viviam: costeños para os litorâneos e llaneros para os do vale central (WEBER, 2007). De modo similar, as palavras komántcia e apachú, que nos idiomas shoshone e atapascano, respectivamente, significavam inimigo, foram utilizadas pelos espanhóis para denominar os povos nativos como comanches e apaches, etnônimos que acabaram sendo apropriados pelos próprios índios (WEBER, 2007).

Contudo, episódios de etnificação não foram exclusivos do contexto colonial. Há diversos exemplos de como os povos nativos se referiam a seus vizinhos, promovendo processos unilaterais de etnificação. Os incas designavam os povos araucanos pelo termo auca, isto é, selvagem no idioma materno incaico (WEBER, 2007). Os araucanos, por sua vez, agiam da mesma forma em relação aos pampas e patagones, chamando-os de tehuelches (gente selvagem) (WEBER, 2007).

Enquanto determinados povos nativos que habitavam a região do Chaco sulamericano se denominavam avas (homens por excelência), os nativos de fala quéchua os 
chamavam depreciativamente de chiriguanos (merda fria) (WEBER, 2007). No período colonial, este etnônimo foi apropriado pelos hispânicos para se referirem a quase todos os grupos indígenas não submetidos que ocupavam o Gran Chaco.

Por seu turno, os guaranis, antes mesmo do contato, chamavam certos grupos chaquenhos por palavras pejorativas, os guaykurus (que em guarani quer dizer gente malvada e suja) e mbyas (que significa esteira, em alusão às habitações portáteis que estes possuíam). Segundo Francismar A. L. Carvalho, “a partir do século XVII, os Guaykuru e os Mbayá se fundem e passam a reivindicar uma identidade própria. Os etnônimos Mbayá e Guaykuru, cunhados pelos Guarani e amplamente utilizados pela administração espanhola, acabaram contribuindo para a emergência identitária dos Mbayá-Guaykuru" (2006, p. 9-10).

Ao abordar a complexidade dos processos etnogênicos, Frank Salomon e Stuart Schwartz mostram que estes vão bem além da emergência de novas configurações indígenas a partir de bases nativas sob influência do contato colonial. Isto é, a etnogênese não se resume a um sentido único de formação de novas identidades étnicas indígenas. Muitos sujeitos oriundos de sociedades estrangeiras acabaram sendo transformados no contato com os autóctones americanos.

De modo geral, se, por um lado, o contexto colonial produziu índios europeizados, por outro, forjou também europeus indianizados (SALOMON; SCHWARTZ, 1999; WEBER, 2007). Nas palavras de Salomon e Schwartz, "em alguns casos, as fronteiras de colonização europeias falharam e deixaram bolsões de colonos presos. Lá ex-grupos transfronteiriços europeus 'indianizaram-se' e se transformaram em novos povos indígenas separados" (SALOMON; SCHWARTZ, 1999, p. 471).

Tanto europeus indianizados como os índios europeizados, por dominarem códigos de conduta de ambos os polos da relação colonial, tiveram condições privilegiadas para agir como mediadores entre as distintas esferas políticas da sociedade americana. Ao se referir especificamente aos espanhóis indianizados, David J. Weber escreve que, nas regiões limítrofes do império hispânico com populações não subordinadas, eles facilitaram os acordos entre índios independentes e as autoridades espanholas. Atuando como tradutores, ajudaram a construir um clima de confiança e entendimento mútuo (WEBER, 2007).

No profícuo ensaio de Salomon e Schwartz, estes autores discorrem inúmeros tipos de processos etnogênicos que se manifestaram na América do Sul. Entre eles, vale destacar aquele que se caracteriza sobretudo pelo envolvimento institucional da Igreja Católica. Na avaliação dos autores, o processo de conversão e as missões cristãs interromperam o que 
chamam de reprodução simbólica por todos os recantos da América. A ação missionária promoveu a realocação física de povos indígenas, criando dependências econômicas, epidemias e subordinação legal dos índios como neófitos. Ademais, as pressões fiscais e políticas dos Estados europeus ensejaram uma tendência de mistura de povos nestes espaços missionais. Assim, o projeto missionário "em muitos lugares produziu sociedades sintéticas e heterogêneas nas quais identidades étnicas antigas foram ofuscadas por uma nova identidade coletiva originalmente imposta de fora" (SALOMON; SCHWARTZ, 1999, p. 458).

Para Guillermo Wilde (2009), as populações indígenas reduzidas nas missões jesuíticas do Paraguai passaram por uma experiência de etnogênese missional. Para o autor, o guarani missioneiro emergiu no transcurso de um longo período de relação entre grupos e atores socioculturais muito diversos, os quais se envolveram numa complexa e peculiar interação econômica, política, jurídica e simbólica. Segundo o autor, ocorreu a homogeneização de uma população indígena diversificada através de um ordenamento espaçotemporal estabelecido por meio da vida nas reduções, do trabalho coletivo e dos preceitos cristãos.

De maneira geral, a malha social americana foi forjada por meio de uma miríade de processos de etnogênese condicionados pelas circunstâncias históricas do contato colonial e de fatores locais específicos. Em determinadas áreas, os grupos étnicos emergidos se assentaram de maneira tão sólida que conseguiram se constituir em forças ativas capazes de interferir no equilíbrio do regime colonial. Nestes espaços, estabeleceu-se uma cultura de contato, ${ }^{\text {iv }}$ ou seja, uma área de inteligibilidade mútua entre as etnias indígenas e as sociedades euro-americanas (WHITE, 2011). Em estudo recente, ao articular os conceitos de middle ground, construído por Richard White, e de etnogênese missional, defendida por Guillermo Wilde, sustento que o processo de etnogênese do guarani missioneiro viabilizou o desenvolvimento de uma cultura de contato que pautou as interações entre esta população indígena e as sociedades euro-americanas no espaço platino na porção meridional da América do Sul. Em outros termos, defendo que, ao promover a estruturação do complexo reducional guaranítico como uma comunidade sociopolítica capaz de influenciar no equilíbrio de forças no Prata, o processo de etnogênese do guarani missioneiro ensejou a emergência de uma cultura de contato, a qual pautou as interações entre as sociedades indígenas e euro-americanas de meados do seiscentos até as primeiras décadas do XIX (FONTELLA, 2017).

Porém, independentemente do modo como cada um desses processos etnogênicos 
ocorreu, não se pode perder de vista que todos eles se inscrevem necessariamente num contexto de tensão e embates. A respeito desta dimensão das interações entre sociedades que provocam fenômenos de etnogênese, de etnificação e, algumas vezes, de etnocídio, o antropólogo Gerald Sider (1994) chama a atenção para um aspecto que, segundo sua avaliação, não pode ficar em segundo plano, qual seja, a violência inerente aos processos que envolvem relações de dominação. As proposições de Sider provocaram um impressionante impacto na produção etno-histórica nos EUA nas últimas três décadas ao influenciar um importante grupo de antropólogos que se dedicou a estudar os processos de formação e as reconfigurações socioidentitárias de inúmeras populações indígenas americanas ao longo do período colonial. Na próxima seção, apresento os principais argumentos que compõem o esquema conceitual elaborado por Geral Sider.

\section{A cultura como uma arena de conflitos: a etnogênese por Gerald Sider}

Em um ensaio seminal sobre esta forma de abordagem, Gerald Sider propõe um debate sobre o tema da identidade como história. Embora seja um texto consideravelmente conhecido, apresentarei aqui uma síntese do argumento defendido pelo autor. Em primeiro lugar, destaca-se que Sider tinha como preocupação central "compreender e encontrar maneiras de ajudar nas lutas contra a dominação que não são diretamente enraizadas em confrontos de classe" (SIDER, 1994, p. 109).

Em sua elaboração teórica, o autor concentra a discussão sobre a formação e destruição históricas das identidades dos povos (étnicos e tribais), ${ }^{\mathrm{v}}$ compreendendo as múltiplas maneiras que as pessoas reivindicam e negam histórias quando reivindicam e negam identidades; e sugere que, para permitir uma melhor percepção/elaboração de estratégias de lutas e sobre dinâmicas de identidades, o conceito de cultura seja reformulado, inserindo a violência no cerne dos processos que formam e transformam a cultura, para assim construir estratégias de contestação à dominação. Sider considera que a dinâmica central do conceito de cultura é a percepção de que ela é concomitantemente compartilhada e não compartilhada. Ou seja, uma espécie de arena de conflitos, onde os sujeitos e/ou grupos sociais lutam para criar histórias conceituais e materiais distintas e contínuas no interior e contra a história normativa, a qual é apropriada ou negada por aqueles mesmos sujeitos e/ou grupos. Nesse sentido, esse conceito de cultura permite abordar lutas que são simultaneamente contra a dominação e entre os dominados. 
A análise de Sider se pauta principalmente a partir de suas experiências de pesquisa etno-históricas com povos nativos do sudeste da América do Norte, mais especificamente sobre o povo lumbee que habitava as regiões das atuais Carolina do Norte, da Carolina do Sul e adjacências. Para o autor, as sociedades nativas que ocupavam estes territórios no período colonial se formaram no bojo de cinco processos de diferenciação e separação antagonistas:

a) a rápida separação entre a dinâmica histórica dos sistemas sociais nativos do pré e pós-contato;

b) o desenvolvimento de tipos cada vez mais diferentes e divergentes de formas sociais nativas. Deste processo, surgiram três tipos fundamentais de sociedades nativas:

a. confederações comerciais, escravistas, militarizadas e mercenárias como os cherokee, os choctaw e alguns grupos creek;

b. pequenos assentamentos tributários, mais próximos ou dentro do território da linha do assentamento colonial, que foram integrados na economia política colonial;

c. comunidades autônomas nativas, cuja autonomia residia na invisibilidade social, baseando-se no formato e nas atividades econômicas de pequenos povoados coloniais;

c) o surgimento de sociedades indígenas cada vez mais separadas e distintas, cada uma com limites cada vez mais firmes e fixos, dentro de cada forma geral de sociedades nativas;

d) a crescente intensificação da diferenciação interna faccional dentro das comunidades políticas nativas pós-contato (nações, tribos ou cidades), o que gerou guerras civis e, até mesmo, a formação de entidades políticas e culturais separadas e/ou novas como o grupo seminole, surgido de um segmento dos creek;

e) a separação cada vez maior dos índios, dos brancos e dos negros, a qual se expressou em ideias sobre diferentes tipos de pessoas e, simultaneamente, na organização social da vida diária e do trabalho.

Em sua avaliação, “todas essas formas de diferenciação foram impostas 'de cima', como parte do processo de dominação" (SIDER, 1994, p. 112) e criaram uma onda que transformou todo o conjunto das organizações sociais, políticas, culturais e cerimoniais dos povos aborígenes americanos. Entretanto, ao mesmo tempo em que foram impelidas pelo transcurso do contato colonial, tais formas passaram a ser reivindicadas pelos próprios sujeitos e/ou grupos como parte dos processos de afirmar seus próprios interesses, de resistir 
e/ou de se adaptar à dominação. Como resultado disso, desencadeou-se, entre os povos nativos, a intensa emergência de novas formas culturais, as quais derivam da relação de incorporação ou não das populações indígenas à economia política colonial euro-americana. Nesse contexto, diante dos distintos modos de como se integravam ou não ao complexo político e econômico colonial, os grupos indígenas elaboraram suas próprias reivindicações, afirmações e agendas.

Entretanto, as tensões e lutas não residem apenas entre os dois principais polos da relação de absorção ou não dos povos indígenas à autoridade política e econômica euroamericana. Uma vez que os conjuntos humanos não são homogêneos, em boa medida elas se manifestam no interior dos próprios grupos sociais envolvidos nas dinâmicas da complexa formação social colonial. Neste plano interno, processam-se conflitos sobre a hegemonia de identidades etno-históricas, isto é, disputas sobre quais significados, símbolos e valores serão ou não compartilhados pelos integrantes do grupo, e se eles reforçam ou contestam a cultura normativa. Nestes cenários, permanentemente tensionados, é que emergem novos modos de os indivíduos e/ou grupos se relacionarem entre si e com a sociedade dominante. Portanto, os espaços de tensão configuram-se como matrizes onde novos conjuntos sociais e culturas tomam forma e vida, assumindo identidades etnohistóricas que flutuam entre dois extremos: a apropriação do padrão valorativo hegemônico ou, então, resistindo à preponderância deste. Nesta lógica, o processo de dominação comporta uma contradição fundamental. Segundo Sider, se, por um lado, os laços sociais entre e dentre os dominados são cruciais para colocar em risco a permanência do domínio, por outro, ajudam a garantir a continuidade da dominação política, simbólica e também a extração de excedentes econômicos.

Deste imbricado e tensionado complexo de relações sociais que envolvem fenômenos de dominação, resistência, construção e desconstrução de identidades, Sider destaca dois pontos que considera universais nas experiências históricas de emergência de formas sociais com base em manifestações culturais étnicas: 1) o entrelaçamento da resistência com a construção de etno-histórias; 2) a associação da existência de facções no interior dos povos dominados com a formação de visões etno-históricas diversas e divergentes.

Traçando um paralelo entre o conceito de luta de classes e a opressão de povos étnicos, baseado na história social marxista britânica, Sider defende que "o núcleo da luta de classes de lutas sempre mais amplas e mais complexas é a mudança [...]. Se [...],formamos nossa agência a partir de nossa experiência, então a agência operária deve 
ser formada contra suas experiências" (1994, p. 118). No que tange à opressão étnica, argumenta o autor, "os povos 'étnicos' oprimidos e explorados também devem se colocar contra sua própria história e suas próprias experiências, também devem reivindicar o novo contra o velho. Mas as lutas sobre a identidade de um povo [...] têm uma relação diferente, mais contraditória com a história do que as lutas de classes” (SIDER, 1994, p. 118).

Esta contradição se caracteriza pela necessidade da emergência de uma identidade étnica baseada numa narrativa de exaltação da trajetória histórica do grupo com a promessa de um futuro triunfante. Porém este passado idealizado de glórias vincula-se intimamente ao rol simbólico e de representações sociais que se originam no processo de dominação (mesmo que sejam selecionados episódios e emblemas de resistência ao domínio) e, desse modo, configura-se como totalmente inadequado como alicerce para a resistência. Nas palavras de Sider, "a contradição cultural central para as lutas baseadas na identidade étnica é que as pessoas não podem reivindicar a identidade histórica que construíram em resistência e separação parcial da dominação, pois reivindicar tal identidade é reconstruir a dominação" (1994, p. 118). Para o autor, não há como sustentar políticas de resistência ou profundas transformações a partir de identidades etno-históricas autoproclamadas que são formadas com base em experiências e/ou símbolos extraídos dos contextos de dominação. De outro modo, em virtude das identidades impostas aos povos étnicos oprimidos pela sociedade dominante serem significativamente pejorativas, elas não podem servir como plataformas de partida para sólidas mobilizações de resistência e transformações, pois são demasiadamente brutais para serem utilizadas como sustentáculo de negação.

Portanto, em processos em que o componente étnico é o motivador dos embates da dialética da dominação, em geral o fenômeno da resistência étnica (bem como conivência, acomodação e distanciamento) se associa à construção de etno-histórias, as quais não podem sustentar os encargos político-simbólicos de um embate que venha a obter transformações significativas. Tal incapacidade condiciona a resistência étnica a um estado de fragmentação já que, devido à heterogeneidade dos grupos sociais, surgem no interior destes diversas opções etno-históricas que, por sua vez, estabelecem e reivindicam identidades distintas entre um mesmo povo étnico. No entanto, o posicionamento do grupo étnico dentro e contra a sociedade dominante institui-se como uma referência fundamental que orienta a aproximação e o distanciamento entre as identidades étnicas alternativas no interior dos agrupamentos. Assim, a elaboração de etno-histórias alternativas, o afastamento entre as etno-histórias que divergem mais profundamente e a aproximação entre aquelas que se assemelham mais do que discordam estabelecem uma dinâmica de construção de 
identidades étnicas mais gerais, e destas mesmas divergências e conciliações emerge a base cultural para a separação e oposição em relação à sociedade e à cultura hegemônicas. De modo literal, Sider explica que "o ponto de partida para formar uma práxis para as lutas e necessidades dos povos étnicos é que tais povos devem experimentar contínua e rotineiramente divisões profundas dentro e contra 'a mesma' identidade global" (1994, p. 120).

De acordo com a elaboração conceitual de Sider, as tensões étnicas internas geram constantemente processos de diferenciação que dão vida a identidades étnicas, as quais, ao divergirem ou conciliarem entre si, pautadas pela sobredita referência fundamental, produzem um cabedal simbólico-político para a contestação da opressão étnica. Ou seja, na dialética da opressão étnica, o tensionamento das relações entre os próprios oprimidos é a fonte para o desenvolvimento de práticas de lutas e resistência mais sólidas. Conforme conclui o autor,

\footnotetext{
há uma associação entre a contínua diferenciação interna de um povo étnico e a formação e reforma constante de diversas visões e reivindicações etno-históricas. O processo de diferenciação assume sua componente "cultural" através da formação dessas visões etnohistóricas. Tais visões, quaisquer que sejam suas outras características, situam ordinariamente, de forma bastante explícita, a identidade dentro e contra a sociedade maior, e entre e contra os outros. [...]. É [...] essa divisão fluída e sempre em mutação, que é dada voz tanto em etno-histórias claramente divergentes como em relações sociais necessariamente ambíguas e entrelaçadas, que devem ser mobilizadas (SIDER, 1994, p. 120).
}

\section{Referências}

BOCCARA, G. Mundos nuevos en las fronteras del Nuevo Mundo: Nuevo MundoMundos Nuevos, [s. 1.], 2005a. Disponível em: 〈https://nuevomundo.revues.org/426>. Acesso em: 19 jul. 2019.

BOCCARA, G. Génesis y Estructura de los Complejos Fronterizos Euro-Indígenas. Repensando los Márgenes Americanos a partir (y más allá) de la obra de Nathan Wacthel. Memória Americana, [s. 1.], v. 13, p. 21-52, 2005 b.

CARVALHO, F. A. L. de. Etnogênese Mbayá-Guaykuru: notas sobre emergência identitária, expansão territorial e resistência de um grupo étnico no vale do rio Paraguai (c. 1650-1800). Fênix: Revista de História e Estudos Culturais, [s. 1.], v. 3, n. 4, p. 1-20, 2006.

FONTELLA, L. G. As missões guaraníticas num contexto de cultura de contato: uma interpretação sobre as interações entre sociedades indígenas e euro-americanas (c.1730 c.1830). 2017. Tese de doutorado - PPGHIS/UFRJ, Rio de Janeiro, 2017.

HICKERSON, N. P. Ethnogenesis in the South Plains Jumano to Kiowa? In: HILL, J. D. 
(Ed.). History, Power, and Identity: Ethnogenesis in the Americas, 1492-1992. Iowa: University of Iowa Press, 1996, p. 70-89.

HILL, J. D. Introduction: Ethnogenesis in the Americas, 1492-1992. In: HILL, Jonathan D. (Ed.). History, Power, and Identity: Ethnogenesis in the Americas, 1492-1992. Iowa: University of Iowa Press, 1996, p. 1-19.

MONTEIRO, J. M. Tupis, tapuias e historiadores: estudos de história indígena e do indigenismo. 2001. Campinas: Unicamp, 2001.

SALOMON, F; SCHWARTZ, S. New peoples and new kinds of people: adaptation, readjustment, and ethnogenesis in south american indigenous societies (Colonial Era). In: SALOMON, F; SCHWARTZ, S. (Eds.). The Cambridge History of the Native Peoples of the Americas, Cambridge New York: Cambridge University Press, 1999. v. III parte 2.

SIDER, G. Identity as history ethnohistory, Ethnogenesis and Ethnocide in the Southeastern United States. Identities Global Studies in Culture and Power, [s. 1.], v. 1, n. 1, p. 109-122, 1994.

WACHTEL, N. A aculturação. In: LE GOFF, J; NORA, P. (Eds.). História: novos problemas. Rio de Janeiro: Francisco Alves, 1995, p. 113-129.

WEBER, D. J. Bárbaros: Los españoles y sus salvajes en la era de la Ilustración. Barcelona: Editorial Crítica, 2007.

WHITE, R. The Middle Ground Indians, Empires, and Republics in the Great Lakes Region, 1650-1815. Cambridge: Cambridge University Press, 2011.

WHITEHEAD, N. L. Ethnogenesis and Ethnocide in the European Occupation of Native Surinam, 1499 1681. In: HILL, Jonathan D. (Ed.). History, Power, and Identity: Ethnogenesis in the Americas, 1492 1992. Iowa: University of Iowa Press, 1996. p. 20-35.

WILDE, G. Religión y poder en las misiones guaraníes. Buenos Aires: SB, 2009.

Submetido em: 29/08/2019

Aprovado em: 05/10/2019

Publicado: 15/12/2019

\section{Notas}

\footnotetext{
' Doutor em História Social pela Universidade Federal do Rio de Janeiro (PPGHiS-UFRJ), mestre em História pela Universidade Federal do Rio Grande do Sul (PPGH-UFRGS), licenciado em História pela Universidade Franciscana (UFN) e professor de História do Instituto Federal Farroupilha, campus São Borja (IFFar-SB).

ii Tais quais: pureza biológica versus mestiçagem, mito e tradição versus história e sociedades frias versu sociedades quentes. "Os sul-americanistas substituíram a noção lévi-straussiana de sociedades ameríndias como 'frias', 'míticas' e a-históricas, com vários estudos de caso demonstrando que os povos indígenas amazônicos e andinos já haviam formulado formas dinâmicas de entender seus passados históricos e que eles eram capazes de transformar esses modos indígenas de interpretação histórica em compreensões coerentes dos europeus e suas formas alienígenas de doença, tecnologia e governança” (HILL, 1996, p. 8).
}

iii No tocante ao conceito de aculturação, este ocupa lugar central na reflexão teórica de Wachtel (1995). 
iv Cunhei o termo cultura de contato para me referir ao que White (2011) chama de middle ground.

${ }^{\vee}$ Reproduzo aqui a ressalva feita por Sider no que se refere à utilização dos termos etnia e tribo: "Prefiro evitar os termos 'étnico' e 'tribal', tanto quanto possível, pois esses termos muitas vezes têm escondido parcialmente implicações reais globais que os tornam utilizáveis apenas com muita cautela, ou como indicadores, não como rótulos para tipos de grupos sociais e categorias. Quando, por exemplo, o governo nigeriano afirmou há alguns anos que seus povos constituintes não deviam ser chamados de 'tribos', mas de 'grupos étnicos', estava escondida entre todas as múltiplas referências históricas nessa mudança (as tribos referenciam o colonialismo e são muitas vezes usadas como um posição inferior 'primitivista') uma posição firme para alargar e consolidar o poder do Estado sobre o campo: ‘tribos' têm suas próprias formas de organização política e controle; 'grupos étnicos' são bem menos estruturados nesse sentido. Assim, prefiro usar o termo politicamente mais aberto, 'povos', com as lutas sobre a forma política que esse povo toma em qualquer momento histórico discutido separadamente" (SIDER, 1994, p. 121, nota 2). 